\title{
A critical analysis of the meaning of the term 'value' in Section 30(6)(e) of the Companies Act
}

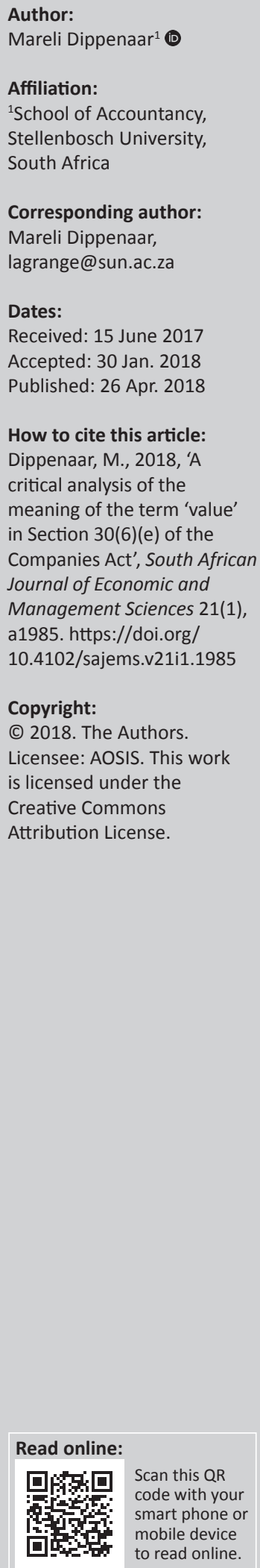

Background: Sections 30(4) and 30(5) of the Companies Act 71 of 2008 (the Act) require, inter alia, disclosure of the remuneration received by each director in a company's annual financial statements. Section 30(6) defines the term 'remuneration', which includes, inter alia, in Section $30(6)(e)$ the 'value' of any option or right granted to a director, as contemplated in Section 42, which deals with options for the allotment or subscription of securities or shares of a company. It is uncertain what the intended meaning of the term 'value' is in this context and it is interpreted differently by different companies in practice.

Aim: The objective of this study was to understand the meaning of the term 'value' in Section 30(6)(e) of the Act (including the date of measurement thereof), as intended by the legislature.

Setting: This article examined existing literature in a South African corporate and legislative environment.

Method: A non-empirical study of existing literature was conducted by performing a historical analysis within a South African context. A doctrinal research approach was followed.

Results: Possible interpretations of the term 'value' include the grant date fair value of the rights, the fair value at reporting date, the fair value on vesting date, the expense calculated in terms of the International Financial Reporting Standard on share-based payments, the gain on exercise of the rights and the intrinsic value on reporting date. It is submitted that the most likely meaning is the grant date fair value.

Conclusion: It was found that the meaning of the term 'value', for purposes of Section 30(6)(e) of the Act, is unclear and interpreted differently by different companies. It is, therefore, recommended that the wording of Section 30(6)(e) is amended to reflect the meaning intended by the legislature.

\section{Introduction}

Sections 30(4) and 30(5) of the Companies Act 71 of 2008 (the Act) require disclosure of certain information in a company's annual financial statements, including the remuneration, as defined in subsection (6), and benefits received by each director or individual holding any prescribed office in the company. Section 30(6) contains details of what the term 'remuneration' referred to in Sections 30(4) and 30(5) includes and is a very broad concept. Section 30(6)(e), read together with Section 30(4), requires the disclosure (per director) of 'the value of any option or right given directly or indirectly to a director, past director or future director, or person related to any of them, as contemplated in Section $42^{\prime}$. Section 42 deals with options for the allotment or subscription of securities or shares of a company.

According to Steyn and Cairney (2016), very few companies actually disclose the value of longterm incentive compensation, which includes share-based payments (SBPs), and generally these values need to be calculated by the users of financial statements, using the information published in the companies' remuneration reports. According to Voller (2016), companies are not disclosing directors' remuneration properly in their annual financial statements, as required by the Act. PWC (2015:13) has also found that 'the overall level of long-term incentives ... disclosure is not yet on par with global standards'.

The term 'value', as used in Section 30(6)(e), is not defined in the Act and its meaning is unclear. Scrutiny of some listed companies' annual financial statements confirmed that companies interpret this disclosure requirement differently, with values varying between 'gross' values, such as fair value on grant date or annualised grant date fair values, to 'net' values, such as gains on exercise of share options only or of all share incentives exercised (or combinations thereof) (Dippenaar \& 
Steenkamp 2017). The uncertainty regarding which 'value' is required to be disclosed by the Act (including the measurement date and appropriate valuation method) and the inconsistent interpretations applied by companies reduce the comparability of companies' annual financial statements for shareholders and other stakeholders. The objective of this study is to understand the meaning of the term 'value' as used in Section 30(6)(e) of the Act, including the date of measurement thereof, as intended by the legislature. There is currently no guidance available regarding the meaning of this disclosure requirement. The study can potentially highlight areas for improvement or, at the very least, for consideration by the Minister of Trade and Industry to clarify the meaning of the term 'value' in Section 30(6)(e) of the Act. The study can potentially also assist companies to understand the intended meaning when preparing the disclosure in their annual financial statements. This could enhance comparability of companies' annual financial statements.

\section{Research methodology}

A non-empirical study of existing literature was conducted by performing a historical analysis within a South African context. A problem-based doctrinal research approach was followed, using interpretive and qualitative analysis. The following steps, as suggested by Hutchinson and Duncan (2012), were followed to solve the specific research problem:

- Assemble the relevant facts.

- Identify the legal issue at hand.

- Analyse the issue from a legal perspective.

- Study relevant background material such as dictionaries and journal articles.

- Locate primary research sources such as case law and legislation.

- Interpret, analyse, compare and combine all issues within the context.

- Reach a tentative conclusion.

This research objective was achieved by investigating the following:

- The meaning of the term 'value' as used in Section 30(6) (e) of the Act (including the date of measurement thereof), by exploring the ordinary definition thereof and attempting to use logical reasoning in order to determine the most likely meaning, as there is no specific guidance available in this regard.

- The impact of the different possible interpretations of the term 'value' in Section 30(6)(e) of the Act on companies' annual financial statements.

During the study, it was found that a possible interpretation of 'value' is 'fair value' (as discussed later). Different techniques could be applied to appropriately determine a fair value. It is, however, not in the scope of this study to evaluate or prescribe a specific valuation technique.

The study is structured as follows: a brief discussion of the relevant aspects and principles of interpretation of legislation is presented. This is followed by a summary of all the possible literal (ordinary) meanings of the term 'value'. Thereafter, the context of the wording in Section 30(6)(e) is explored in an attempt to determine the intended meaning of 'value'. The possible interpretations of the term are discussed based on the types of SBPs in use and the regulatory frameworks that govern the disclosure of SBPs and a logical reasoning is applied in an attempt to determine the most likely meaning. A practical illustration of the impact of each possible interpretation on a company's financial statement disclosure is presented and a conclusion regarding the most likely interpretation intended by the legislature, based on the literature study performed, is finally presented. Lastly, recommendations for the amendment of the existing wording in Section $30(6)$ (e) are made and a future research opportunity is highlighted.

\section{Interpretation of words used by the legislature Principles of interpretation}

The golden rule of interpreting statutes, subject to certain exceptions, is to apply the literal or ordinary meaning of the words used to determine the intention of the legislature, when the words are clear and unambiguous (Venter $v$ R [1907] TS 910). In order to do so, the grammatical meaning of the words should be applied and dictionaries can be helpful in this regard. However, if a word is used in a technical sense, it has to be interpreted using its technical meaning, that is, its meaning within a specific trade, business or profession and not its ordinary meaning (De Ville 2000). Sometimes the intention of the legislature could be ascertained by referring to the context of the statute. This is usually when the ordinary meaning would be unreasonable or unconstitutional or lead to an ambiguity, absurdity or inconsistency (Devenish 1992; De Ville 2000; Ngcobo and Others v Salimba CC; Ngcobo v Van Rensburg 1999 [2] SA 1057 [SCA]). 'Value', as used in Section $30(6)(e)$, is not so much ambiguous, but it is simply too vague to establish its true meaning in the context of the section. It is possibly even incomplete, as it does not specify what value should be used or on what date the value should be determined. In order to determine the context of a word, we refer to the scope and purpose of the specific section of the Act, as well as to its background (De Ville 2000; Jaga v Dönges NO 1950 [4] SA 653 [A] 662).

\section{The literal meaning}

There is no definition of 'value' in the Act; however, based on the dictionary meaning (Oxford English Dictionary 2017), 'value' is commonly understood as, inter alia:

... the material or monetary worth of something; the amount at which something may be estimated in terms of a medium of exchange, as money or goods, or some other similar standard ... [or] ... the relative worth, usefulness, or importance of a thing or (occas.) a person; the estimation in which a thing is held according to its real or supposed desirability or utility. 
TABLE 1: Terminology used in International Financial Reporting Standards to specify a type of value (listed alphabetically).

\begin{tabular}{lll}
\hline Actuarial present value & Carrying value & Economic value \\
Embedded value & Entity-specific value & Expected value \\
Fair value & Intrinsic value & Market value \\
Monetary value & Net asset value & Net realisable value \\
Nominal value & Par value & Present value \\
Redemption value & Residual value & Scrap value \\
Settlement value & Surrender value & Time value \\
Value in use & - & - \\
\hline
\end{tabular}

Other definitions include 'the worth of a thing in money or goods at a certain time; market price' (Webster's New World College Dictionary n.d.) or 'the balance between what a customer sees as the benefit to them of a product and the price they have to pay for it' (Collins English Dictionary 2017). A value can usually be expressed in a currency.

\section{The technical meaning}

Seeing that Section 30(6)(e) of the Act deals with the disclosure of directors' remuneration and, specifically, with share incentives, 'value' is possibly used in a technical (accounting) sense in this context. International Financial Reporting Standards (IFRS), however, do not define 'value'. IFRS (and the accompanying illustrative examples) usually do not even use the standalone term 'value', but specify the type of 'value' (Table 1). All of these different 'values' have different meanings, so they are either defined or IFRS explain how that value should be determined. Accounting standards were originally named International Accounting Standards (IAS) but newer standards (issued by the current standard setting body) are named 'IFRS'. Collectively these standards (including IAS and IFRS standards) are also referred to as 'IFRS'. When reference is made to an individual standard, it is referred to as 'IAS $x$ ' or 'IFRS $x$ ' ( $x$ being the number of the specific standard).

When IFRS use the term 'value', without specifying which value, it is understood in its ordinary sense, namely the monetary worth of something. An example is when IFRS 16 Leases (IFRS 16) refers to 'asset ... of low value' (IFRS 16.6) or when IAS 20 Accounting for Government Grants and Disclosure of Government Assistance (IAS 20) refers to 'those ... which cannot reasonably have a value placed upon them' (IAS 20.3). However, whenever IFRS require disclosure of a value, the standard would specify the type of value or how that value needs to be determined. Even when it appears to only refer to 'value' (as a standalone term), it has usually been specified earlier in that standard or section what was meant by 'value', for example a 'fair value', which is a term that is defined (IFRS Foundation 2016). Table 2 provides examples of such uses in IFRS. 'Value' is also usually understood to be a gross value and not a net value (such as, for example, the difference between two values - i.e. a gain), although exceptions exist.

Since the literal meaning of the term 'value' is too vague to understand what is meant in Section 30(6)(e) and IFRS do
TABLE 2: Some examples where 'value' is used as a standalone term in International Financial Reporting Standards.

\begin{tabular}{|c|c|}
\hline $\begin{array}{l}\text { Extract of wording used } \\
\text { (own emphasis added) }\end{array}$ & Meaning of 'value' in this context \\
\hline $\begin{array}{l}\text { 'the net realisable value or recoverable } \\
\text { amount ... translated at the exchange } \\
\text { rate at the date when that value was } \\
\text { determined' (IAS } 21.25[\mathrm{~b}]) \text {. }\end{array}$ & $\begin{array}{l}\text { Net realisable value or recoverable } \\
\text { amount, as specified earlier in the } \\
\text { sentence. }\end{array}$ \\
\hline $\begin{array}{l}\text { 'profits and losses on disposal of } \\
\text { investments and changes in value of } \\
\text { investments' (IAS 26.35[b][ix]). }\end{array}$ & $\begin{array}{l}\text { Actuarial present value, since this } \\
\text { is what this standard specifies as } \\
\text { the measurement basis of these } \\
\text { types of items. }\end{array}$ \\
\hline $\begin{array}{l}\text { 'measure their value ... indirectly, by } \\
\text { reference to the fair value of the equity } \\
\text { instruments granted' (IFRS } 2.10 \text { ). }\end{array}$ & $\begin{array}{l}\text { Fair value, as stated further in the } \\
\text { same sentence. }\end{array}$ \\
\hline $\begin{array}{l}\text { 'recognise an additional expense for } \\
\text { the excess value given, i.e. the } \\
\text { difference between the cash paid and } \\
\text { the fair value of the equity instruments } \\
\text { that would otherwise have been } \\
\text { issued, or the difference between the } \\
\text { fair value of the equity instruments } \\
\text { issued and the amount of cash that } \\
\text { would otherwise have been paid, } \\
\text { whichever is applicable' (IFRS } 2.43[\mathrm{c}] \text { ). }\end{array}$ & $\begin{array}{l}\text { Depending on applicability, the } \\
\text { difference between the cash paid and } \\
\text { the fair value of the equity instruments } \\
\text { that would have been issued or the } \\
\text { difference between the fair value of } \\
\text { the equity instruments and the cash } \\
\text { that would have been paid, as } \\
\text { specified. }\end{array}$ \\
\hline $\begin{array}{l}\text { 'Option value is not a linear function of } \\
\text { option term; value increases at a } \\
\text { decreasing rate as the term lengthens } \\
\ldots \text { calculating estimated option value } \\
\text { on the basis of a single weighted } \\
\text { average life that includes widely } \\
\text { differing individual lives would } \\
\text { overstate the total fair value of the } \\
\text { share options granted' (IFRS 2.B20). }\end{array}$ & $\begin{array}{l}\text { Fair value, as this entire section sets } \\
\text { out to explain how to calculate fair } \\
\text { value in this context. }\end{array}$ \\
\hline
\end{tabular}

share options granted (IFRS 2 B20).

IFRS, International Financial Reporting Standards.

not clarify it either (from a technical sense), it is necessary to establish the context of the word within the statute.

\section{The context of Section 30(6)(e)}

The purpose of legislation provides context to determine the scope and intended effect of the law (Thornton 1996). In order to determine purpose, reference is made to Section 5 of the Act, which states that:

... this Act must be interpreted and applied in a manner that gives effect to the purposes set out in section 7 ... [and] to the extent appropriate, a court interpreting or applying this Act may consider foreign company law.

Section 5 does not provide much assistance with interpreting Section 30(6)(e) either. Section 7 of the Act is considered to establish the purpose of the Act, but the purpose is too general in nature and not helpful in determining what could be meant by 'value' in Section 30(6)(e). The explanatory summary of the Companies Bill 2007 was also consulted, but again there was nothing specific in the commentary relating to annual financial statement disclosure or directors' remuneration. In order to consider the background of the section, the history of the section was considered by referring to previous versions of the section.

Section 30(6)(e) was first introduced in the 2008 Act and there were no previous versions of this specific section. The Companies Act that applied before the 2008 Act became effective, was Companies Act 61 of 1973 (the 1973 Act). The 1973 Act contained a Section 297(2A)(g)(i) which appears to be the predecessor of the current Section 30(6)(e) disclosure requirement. Section 297(2A)(g)(i), added in 1999, required the disclosure of: 
... gains made on the exercise of share options, the gain being the difference between the price paid for the shares and the market price of the shares on the date of exercise, and that date being the date on which the director takes ownership of the shares and is entitled to dispose of them.

The original 1973 Act also required the disclosure of directors' emoluments, but 'emoluments' were only later defined when Section 2A was added by the Companies Amendment Act 37 of 1999. The object of this was to improve disclosure and ensure more transparency, by enabling stakeholders to inspect the level of remuneration, without compromising an individual's right to privacy (Republic of South Africa 1999b).

The provisions relating to directors' remuneration disclosure, and specifically to SBPs, were clearly narrower and much more specific in the 1973 Act: it only related to share options, whereas in the 2008 Act it has been broadened to refer to 'any option or right' and it specifically required disclosure of the gain on exercise of the options. It was also more prescriptive, as it required the gains to be disclosed in table format. There was, however, no requirement to make the disclosure per director, as is the case in the 2008 Act. The use of the word 'value' in the new Act can be interpreted in various ways, from variations of gross values like a fair value on certain dates to net values like gains realised on exercise of share options.

\section{Possible interpretations of 'value' based on the types of share-based payments in use}

Examples of SBPs to employees and directors that are commonly used are, share options (a right to purchase shares at a predetermined exercise price), share appreciation rights (a right to receive a cash payment equal to the increase in value of shares from the grant date to the exercise date), phantom shares (a right to receive cash equal to the value of shares) and contingent or restricted shares (where the shares are granted for free) (Massie, Collier \& Crotty 2014; Mavrodinov 2012; Steyn 2015). SBPs are classified as either equity-settled or cash-settled in terms of IFRS 2 Share-based Payment (IFRS 2), based on the nature of the SBP. Table 3 provides a summary of what these schemes are typically classified as in terms of IFRS 2.

Table 4 provides a summary of the possible interpretations of 'value', in the author's opinion, and the types of SBPs to directors for which the values could be relevant. For the purposes of Table 4, two categories of SBPs are identified, namely options or share appreciation rights (including share purchase plans accounted for as options) and shares or phantom shares (including deferred bonus plans which are

TABLE 3: IFRS 2 classifications of typical share-based payments to directors.

\begin{tabular}{lcc}
\hline Type of share-based payment & Equity-settled & Cash-settled \\
\hline Options & $\mathrm{X}$ & - \\
Share appreciation rights & - & $\mathrm{X}$ \\
Contingent or restricted shares & $\mathrm{X}$ & - \\
Phantom shares & - & $\mathrm{X}$ \\
\hline
\end{tabular}

similar to the granting of shares). This classification is based on the fact that options and share appreciation rights could have an exercise date that is different from the vesting date, while shares or phantom shares usually only have a vesting date, which is also the exercise date.

Another possible interpretation of 'value' could include the fair value of the underlying shares (in the case of share options), although it is unlikely that this could be regarded as a 'right', as required by Section 30(6)(e). Similarly, it is unlikely that companies would interpret 'value' in the context of Section 30(6)(e) as meaning the amount payable to exercise the right (i.e. the exercise price). These two 'values' are rather the two items needed to calculate the gain on exercise that was required to be disclosed by the 1973 Act.

The author is of the opinion that the term 'value' in the context of Section 30(6)(e) does not imply a net value like a gain on exercise or an annualised value like the IFRS 2 expense, otherwise the legislature would surely have provided clarification on how to calculate such a value, as was the case in the 1973 Act that provided details on how to calculate the gain. Surely if the term 'value' in Section 30(6)(e) was intended to still mean 'gain on exercise', the legislature would not have changed the wording in the Act completely from what it was in the 1973 Act. In the light of the ordinary meaning of 'value', it would make more sense for 'value' to be interpreted as a gross value, such as 'fair value'. However, if the intention was for a 'fair value' to be disclosed, it is uncertain why the legislature did not use those specific words, as was the case in the other 14 places in the Act where specific mention is made of 'fair value' (inter alia in Section 38(3)(b) relating to share issues). Not only is it unclear if a gross or net value is implied, but if a gross value should be disclosed, then it is uncertain on what date the value should be determined.

\section{Possible interpretations of 'value' based on other regulatory frameworks}

In an attempt to determine the most likely meaning of the term 'value' in Section 30(6)(e), other regulatory frameworks requiring disclosure of SBP to directors were consulted to establish which 'values' these sources require to be disclosed, regardless of whether it should be disclosed per director or in total. It is possible that the legislature intended for the same 'value' to be disclosed. These other sources include IFRS 2 and IAS 24 Related Party Disclosures (IAS 24) (IFRS Foundation 2016), the King Report on Governance for South Africa 2009 (King III) (IoDSA 2009) and the Johannesburg Stock Exchange (JSE) Listing Requirements (JSE Limited 2017). All companies registered in South Africa and that are required to be audited, need to comply with Section 30(4) of the Act, while only those listed or wishing to list on the JSE need to adhere to the listing requirements. Only those companies that are required to, by the Act, or those that choose to apply IFRS, need to comply with the requirements of IFRS 2 and IAS 24. The King code effective at the time of writing this article was King III. King IV replaces King III in its entirety and is effective for 
TABLE 4: Possible interpretations of 'value'.

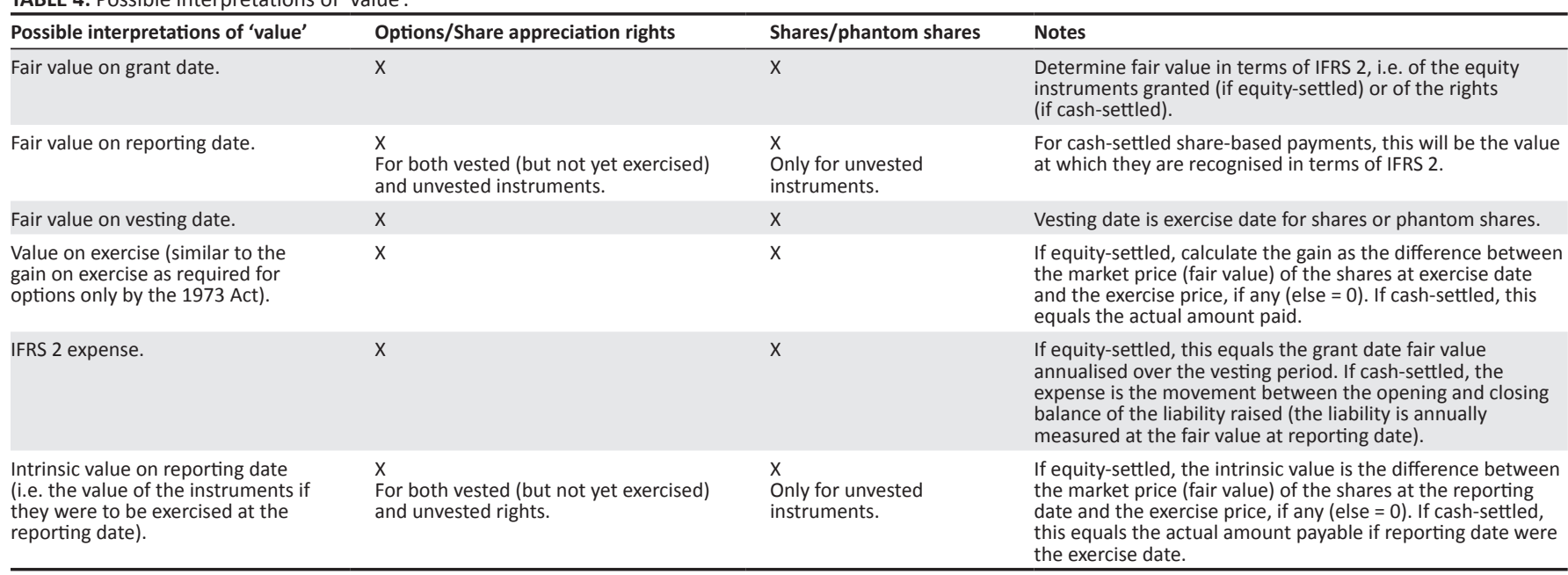

IFRS, International Financial Reporting Standards.

financial years beginning on or after 01 April 2017 (IoDSA 2016). Compliance with King III is not legally binding. However, the JSE listing requirements require that companies apply certain principles of King III (JSE Limited 2017).

Below follows a discussion of the disclosure requirements of these other regulatory frameworks in an attempt to establish the possible meaning of the term 'value' that is used in Section $30(6)(e)$. Consequently, disclosure requirements of narrative or qualitative information, or of quantitative information that is not currency values, such as for example the number of options granted or exercised, are excluded here.

\section{IAS 24}

IAS 24 requires disclosure of the SBP compensation to all key management personnel, including directors, in total (not per individual), that is, the current year IFRS 2 expense. This is a possible interpretation of the term 'value' in the context of Section 30(6)(e), but there are other more likely interpretations, as discussed below.

\section{IFRS 2}

The disclosure requirements of IFRS 2 are set out in Table 5 . A discussion of whether these requirements are possible interpretations of 'value' in the context of Section $30(6)(\mathrm{e})$ is also included in Table 5.

\section{JSE listing requirements}

The JSE listing requirements require disclosure of the exercise price of each option or right outstanding at the beginning of the year, awarded during the year, exercised during the year and outstanding at reporting date. In addition, the price at which shares were issued or allotted (but not yet fully paid for) in terms of a share purchase or option plan (i.e. the exercise price) must also be disclosed.

It is unlikely that 'value' in the context of Section 30(6)(e) should be interpreted as the exercise price, as the amount payable to exercise the right does not constitute the value of
TABLE 5: IFRS 2 disclosure requirements and applicability to Section 30(6)(e).

\begin{tabular}{|c|c|}
\hline Disclosure requirement & $\begin{array}{l}\text { Possible interpretation of 'value' in } \\
\text { the context of Section } 30(6)(e) \text { ? }\end{array}$ \\
\hline $\begin{array}{l}\text { Weighted average exercise price of } \\
\text { various categories of share options, } \\
\text { such as those granted or exercised } \\
\text { during the year, inter alia. }\end{array}$ & $\begin{array}{l}\text { No, unlikely. } \\
\text { An amount payable will likely not be } \\
\text { interpreted as the value of a 'right'. }\end{array}$ \\
\hline $\begin{array}{l}\text { The range of exercise prices for } \\
\text { outstanding options. }\end{array}$ & $\begin{array}{l}\text { No, unlikely. } \\
\text { Same reason as above. }\end{array}$ \\
\hline $\begin{array}{l}\text { Weighted average share price, i.e. the } \\
\text { market price (fair value) at exercise } \\
\text { date for options exercised during the } \\
\text { period. }\end{array}$ & $\begin{array}{l}\text { No, unlikely. } \\
\text { The value of the underlying shares that } \\
\text { can be purchased will likely not be } \\
\text { regarded as a 'right'. }\end{array}$ \\
\hline $\begin{array}{l}\text { For equity-settled instruments: the } \\
\text { weighted average fair value on } \\
\text { measurement date (i.e. grant date) of } \\
\text { options or other equity instruments } \\
\text { granted during the year. }\end{array}$ & $\begin{array}{l}\text { Yes, possibly (grant date fair value). } \\
\text { However, a weighted average value } \\
\text { would not be a good reflection of total } \\
\text { 'remuneration'. }\end{array}$ \\
\hline $\begin{array}{l}\text { Incremental fair value granted as } \\
\text { a result of modifications of } \\
\text { equity-settled SBPs. }\end{array}$ & $\begin{array}{l}\text { No, unlikely. } \\
\text { This requirement is too specific and } \\
\text { would only arise in the limited } \\
\text { circumstances where the terms of the } \\
\text { SBP arrangement are modified. This } \\
\text { does not constitute the full value of } \\
\text { the right either, but is only an } \\
\text { incremental value. }\end{array}$ \\
\hline Total IFRS 2 expense. & Yes, possibly. \\
\hline $\begin{array}{l}\text { Total carrying amount at reporting date } \\
\text { of liabilities recognised in respect of } \\
\text { cash-settled SBPs. }\end{array}$ & $\begin{array}{l}\text { No, unlikely. } \\
\text { These values are only relevant for } \\
\text { cash-settled SBPs, while Section 30(6) } \\
\text { (e) requires disclosure of 'the value of } \\
\text { any option or right' which implies both } \\
\text { cash-settled and equity-settled SBPs. }\end{array}$ \\
\hline $\begin{array}{l}\text { Total intrinsic value at reporting } \\
\text { date of vested SBP-liabilities } \\
\text { (i.e. cash-settled only). }\end{array}$ & $\begin{array}{l}\text { No, unlikely. } \\
\text { Same reason as above. }\end{array}$ \\
\hline
\end{tabular}

SBPs, share-based payments.

the right. The wording of the JSE listing requirements also seems to imply that the disclosure requirements are different from those required by the Act: 'in addition to complying with IFRS, Section 30 of the Act and paragraph 3.84 of the Listings Requirements, issuers are required to disclose the following information' (JSE Limited 2017:par.8.63).

\section{King III}

The author is of the opinion that 'value' in Section 30(6)(e) of the Act should be interpreted to have the same meaning as that specified in King III. The introduction of the Act was the reason for a newer version of the King code (i.e. King III) and it seems as if the purpose of King III and the Act is to require disclosure of the same directors' remuneration values: 
Companies should provide full disclosure of each individual executive and non-executive directors' remuneration, giving details as required in the Act of base pay, bonuses, share-based payments, granting of options or rights, restraint payments and all other benefits (including present values of existing future awards) (IoDSA 2009:par.180, own emphasis added).

King III, read together with the remuneration practice note (IoDSA 2013), requires disclosure of the fair value of shareincentive grants, options or rights and specifies that this value should be based on the expected net present value of the instruments. This constitutes the grant date fair value of the instruments that is expected to vest. The practice note continues to state that best practice would be to disclose the 'value at grant per grant' (i.e. the grant date fair value), 'the value of all unvested/unexercised historical awards at current expected value' (i.e. the reporting date fair value) and 'the value realized from all options exercised or share-based awards settled in the period under review' (i.e. the gain on exercise). It is, therefore, submitted that 'value' in Section 30(6)(e) should be interpreted as grant date fair value and, possibly, also reporting date fair value and gain on exercise.

Although the IFRS 2 expense is not the most likely interpretation of the term 'value' in the context of Section $30(6)(e)$, as discussed, it is not ruled out as a useful value to disclose. According to Urson (2016), it should be mandatory for companies to make more comprehensive disclosure of their compensation schemes on a per director basis. He is of the opinion that companies should disclose both the gain on exercise of share options and the IFRS 2 expense on a per director basis, as this would grant shareholders the necessary flexibility to choose a metric for their own analysis, provide greater transparency and improve comparability, especially with international companies.

\section{Current practice and illustration}

From a preliminary inspection of companies' annual financial statements, it seems that companies are disclosing the following values per director (Dippenaar \& Steenkamp 2017):

- Grant date fair value (required by King III, read together with the remuneration practice note).

- Gain on exercise of share options only (previously required by the 1973 Act, although not required per director).

- Value of all share incentives exercised during the year (seemingly an extension of the 1973 Act's requirement from options only to all share incentives).

- Sufficient information to calculate the value of all share incentives exercised.

- IFRS 2 expense (required by IAS 24 and IFRS 2, but not per director).

- A combination of the above.

Since only the grant date fair value is required to be disclosed per director, it is assumed that these other values noted are disclosed either voluntarily or in an attempt to comply with the Act. The uncertainty regarding which 'value' is required to be disclosed by Section 30(6)(e) and the inconsistent interpretations applied by companies lead to incomparability between similar companies.

The following example illustrates the differences in numbers that companies might disclose in their annual financial statements, depending on their interpretation of the term 'value' in Section 30(6)(e). These differences could be significant in bull or bear market conditions. For purposes of the illustration, a share option plan is used, where the directors have the option to purchase shares in future (during the exercise period), but at an exercise price equal to the share price on the grant date of the options. Share appreciation rights would be similar, except that the directors cannot purchase physical shares, but benefit by receiving cash for the increase in share price from grant date up to exercise date. In respect of plans where shares or phantom shares are granted, the vesting date and exercise date is the same; therefore, these types of plans were not selected to illustrate the full effect of the differences in interpretations of the term 'value'.

Assume that Company $\mathrm{X}$ grants 100 share options to each of its 10 directors on 01 July $20 \times 1$. Company $X$ has a 31 December reporting date. Each grant is conditional upon the director remaining in the service of Company $X$ for another 3 years. In other words, the share options will vest on 30 June $20 \times 4$. The share options can be exercised at an exercise price of 15 rand (R) at any time during the 6 years post vesting date, i.e. by 30 June $20 \times 10$.

The relevant fair values of the shares and share options, throughout the life of the share options, are presented in Table 6 .

On the basis of a weighted average probability, Company $X$ estimated on grant date that two of the directors would leave during the 3-year period and therefore forfeit their rights to the share options. This turned out to be true and eight directors' share options vested on 30 June $20 \times 4$. Five directors exercised their share options on 30 June 20x8, while the other three directors' options expired on 30 June $20 \times 10$, since they were not exercised by that date. Company $X$

TABLE 6: Fair values of shares and options throughout the life of the options.

\begin{tabular}{|c|c|c|}
\hline Date & Fair value per share & Fair value per option \\
\hline 1 July $20 \times 1$ & R15.00 & $\mathrm{R} 2.00$ \\
\hline 31 December $20 \times 1$ & R15.10 & $\mathrm{R} 2.80$ \\
\hline 31 December $20 \times 2$ & R15.80 & $\mathrm{R} 2.55$ \\
\hline 31 December $20 \times 3$ & R16.20 & $\mathrm{R} 2.90$ \\
\hline 30 June $20 \times 4$ & R15.50 & R3.00 \\
\hline 31 December 20×4 & R17.00 & $\mathrm{R} 2.70$ \\
\hline 31 December $20 \times 5$ & R17.10 & $\mathrm{R} 2.85$ \\
\hline 31 December 20×6 & R17.50 & $\mathrm{R} 2.60$ \\
\hline 31 December $20 \times 7$ & R16.40 & $\mathrm{R} 1.80$ \\
\hline 30 June $20 \times 8$ & R16.00 & $\mathrm{R} 1.60$ \\
\hline 31 December $20 \times 8$ & R16.50 & R1.55 \\
\hline 31 December $20 \times 9$ & R16.90 & $\mathrm{R} 1.70$ \\
\hline 30 June $20 \times 10$ & R17.20 & $\mathrm{R} 2.20$ \\
\hline 31 December $20 \times 10$ & R18.00 & $\mathrm{N} / \mathrm{A}$ \\
\hline
\end{tabular}

$\mathrm{N} / \mathrm{A}$, not applicable 
could disclose the following amounts, per director, per year (in Table 7), in its annual financial statements, in respect of the 'value' of the SBPs. The information is presented for each of the financial years from 20x1 until 20x9 (at 31 December each year) and for each of the possible interpretations of 'value' in Section 30(6)(e). No value will be disclosed in 20x10, as the options have expired. Values are rounded to the nearest rand and calculations for the values in Table 7 are provided in Appendix 1.

\section{Conclusion and recommendations}

The meaning of the term 'value', for the purposes of Section 30(6)(e) of the Act, is unclear and can be interpreted in various ways, from variations of 'gross' values such as fair value on certain dates or even annualised values such as the IFRS 2 expense, to 'net' values such as the gain realised on exercise of SBPs or the intrinsic value thereof before exercise. Not only is it unclear if a gross or net value is implied, but if a gross value should be disclosed, then the date on which it should be determined is also uncertain. Since the meaning is unclear and the legislature's intention is unknown, the author attempted to use logical reasoning in order to determine the most likely meaning. The term 'value' is commonly understood as 'the monetary worth' of something. The author is of the opinion that it does not imply a net value like a gain on exercise of share options, as then surely the legislature would have used the existing wording in the 1973 Act. The fact that the wording was completely altered, shows that a different meaning should be ascribed to the term 'value' than gains on exercise of share options.

The author is of the opinion that a fair value should be disclosed, although it is uncertain why the legislature failed to use that exact term in Section 30(6)(e), seeing that 'fair value' is used 14 times in other sections of the Act. Fair value on grant date, reporting date, vesting date and exercise date would all be useful to disclose, but the author is of the opinion that it should be interpreted as the grant date fair value, as required by King III. It could even possibly be extended to also refer to the reporting date fair value and gain on exercise, which are stated as best practice in the King III practice note on remuneration.

The uncertainty regarding the meaning of 'value' in Section 30(6)(e) has significant consequences in terms of comparability of company annual financial statement disclosures and it is recommended that the wording of Section 30(6)(e) is amended to reflect the meaning intended by the legislature. It would be even more helpful if the Act could provide more detailed requirements of how particular components of remuneration should be calculated, as is the case in the United Kingdom in respect of quoted companies (United Kingdom 2013). It is also recommended that the Act is amended to be more prescriptive as to the format to be used for the disclosure, as was the case in the 1973 Act (which required the gain on exercise of options to be provided in a table format) and the United Kingdom, where Part 3 and Part 4 of the regulations to the Companies Act 2006 require disclosure of directors' remuneration to be made graphically in bar graphs and tables (United Kingdom 2013). This would enhance the comparability of companies' disclosures. Other studies (Asafo-Adjei 2015; Madlela \& Cassim 2017) have also found that the Act's minimum standards of remuneration disclosure are too low and agree that the Act should standardise the disclosure of directors' remuneration, similar to that of the United Kingdom.

The level of disclosure of directors' remuneration by companies is still a problem for shareholders and users of financial statements. In order to help address this problem and to assist companies with the preparation of their disclosures, especially those that need to be disclosed per director, as required by so many different sources, future research could include the development of an easy-to-use disclosure checklist.

Fair value could be determined using a variety of valuation techniques. The study is limited as it does not attempt to evaluate valuation techniques nor to prescribe the most appropriate valuation method to determine the fair value of share-based remuneration. A future research study could consider the appropriateness of different valuation methods

TABLE 7: Disclosures of share-based payment 'value', per director, in the 20x1 to 20x9 financial statements of Company X.

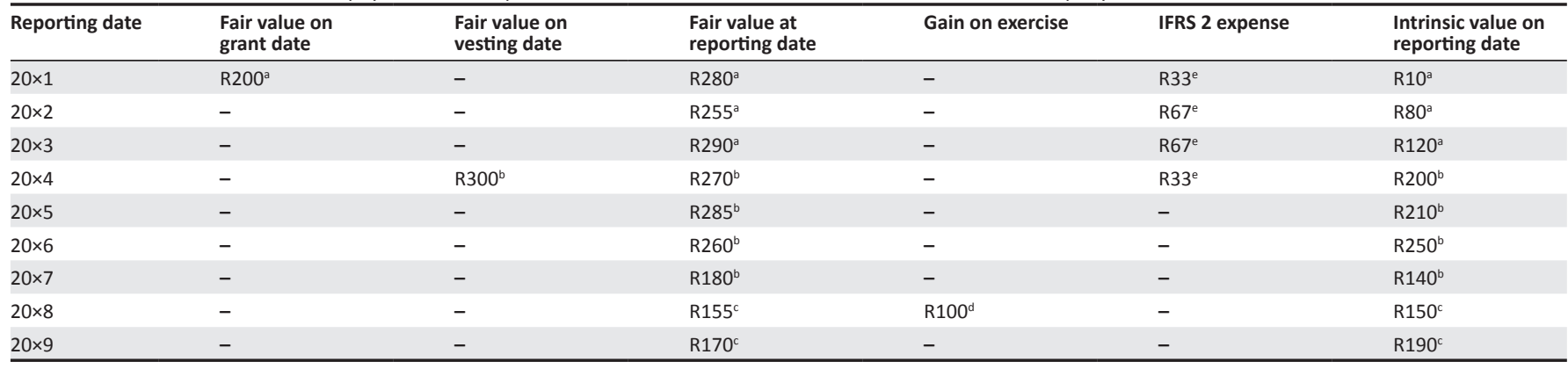

a, This disclosure can also vary in practice. Some could disclose this value in respect of each of the 10 directors that received a grant, while others could disclose it for each director that the company expects will remain in service until the vesting date (i.e. only eight directors).

, This would be disclosed in respect of each of the eight directors in which the rights vested.

c, This value is disclosed for each of the three directors that had not exercised their rights at that date.

${ }^{d}$, The gain is disclosed for each of the five directors that exercised their rights during the year.

e, The IFRS 2 expense is calculated based on the number of directors expected to meet the vesting conditions and is therefore disclosed in respect of each of the eight directors expected to remain in service until the vesting date. 
available or applied by companies to value their share-based incentives.

\section{Acknowledgements Competing interests}

The author declares that she has no financial or personal relationships that may have inappropriately influenced her in writing this article.

\section{References}

Asafo-Adjei, M.A., 2015, 'Regulation of executive directors remuneration in South Africa: The road to achieving good corporate governance', master's thesis, University of Cape Town, Cape Town

Collins English Dictionary, 2017, viewed 22 May 2017, from https://www. collinsdictionary.com/dictionary/english/value

Devenish, G.E., 1992, Interpretation of statutes, Juta \& Co., Ltd., Cape Town.

De Ville, J.R., 2000, Constitutional \& statutory interpretation, Interdoc Consultants Pty Ltd, Cape Town.

Dippenaar, M. \& Steenkamp, G., 2017, 'Disclosure of directors' remuneration' Accountancy SA, November 2017, 54-56.

Hutchinson, T. \& Duncan, N., 2012, 'Defining and describing what we do: Doctrinal legal research', Deakin Law Review 17(1), 83-119. https://doi.org/10.21153/ dlr2012vol17no1art70

IFRS Foundation, 2016, A guide through international financial reporting standards, parts $A 1, A 2, B 1$ and $B 2$, IFRS Foundation, London.

Institute of Directors Southern Africa (IoDSA), 2009, King report on governance for South Africa 2009, IoDSA, Johannesburg.

Institute of Directors Southern Africa (IoDSA), 2013, Practice notes - A guide to the application of King III: Remuneration, IODSA, Johannesburg.

Institute of Directors Southern Africa (IoDSA), 2016, King IV report on corporate governance for South Africa 2016, IODSA, Johannesburg.

Jaga v Dönges NO 1950 (4) SA 653 (A) 662

JSE Limited (JSE), 2017, JSE Limited listing requirements, viewed 26 May 2017, from https://www.jse.co.za/content/JSERulesPoliciesandRegulationltems/JSE $\% 20$ Listings\%20Requirements.pdf

Madlela, V. \& Cassim, R., 2017, 'Disclosure of directors' remuneration under South African company law: Is it adequate?', South African Law Journal 134(2), 383-414.
Massie, K., Collier, D. \& Crotty, A., 2014, Executive salaries in South Africa: Who should have a say on pay?, Jacana Media, Auckland Park.

Mavrodinov, N., 2012, 'The changing landscape of long-term share-based compensation in South Africa', master's thesis, University of Cape Town, Cape Town.

Ngcobo and Others v Salimba CC; Ngcobo v Van Rensburg 1999 (2) SA 1057 (SCA)

Oxford English Dictionary online version, 2017, viewed 22 May 2017, from http:// www.oed.com/view/Entry/221253?rskey=LcoFKv\&result=1\#eid

PricewaterhouseCooper Inc. (PWC), 2015, Executive directors practices and remuneration trends report, 7th edn., South Africa, viewed 02 June 2017, from https://www.pwc.co.za/en/assets/pdf/executive-directors-report07.2015.pdf

Republic of South Africa, 1973, Companies Act 61 of 1973, Government Printer, Pretoria.

Republic of South Africa, 1999a, Companies Amendment Act 37 of 1999, Government Printer, Pretoria.

Republic of South Africa, 1999b, Companies Amendment Bill, Government Printer, Pretoria.

Republic of South Africa, 2007, Companies Bill, Government Printer, Pretoria.

Republic of South Africa, 2008, Companies Act 71 of 2008, Government Printer, Pretoria.

Steyn, F. \& Cairney, C., 2016, 'MAF 08: Long-term incentives: Do shareholders get what they pay for?', in Southern African Accounting Association National Teaching and Learning and Regional Conference Proceedings, Cape Town, South Africa, 02 September, pp. 244-267.

Steyn, G.F., 2015, 'The relationship between CEO compensation and future share returns in South Africa', master's thesis, University of Western Cape, Cape Town.

Thornton, G.C., 1996, Legislative Drafting, 4th edn., Tottel Publishing, United Kingdom.

United Kingdom, 2006, Companies Act 2006, viewed 09 June 2017, from http://www. legislation.gov.uk/ukpga/2006/46/section/421

United Kingdom, 2013, Large and medium-sized companies and groups (accounts and reports) (amendments) regulations 2013 no. 1981, viewed 09 June 2017, from http://www.legislation.gov.uk/uksi/2013/1981/pdfs/uksi_20131981_en.pdf

Urson, M., 2016, 'CEO pay ratios and company performance: A study of JSE-listed consumer goods and services companies', master's thesis, University of Cape Town, Cape Town

Venter v R [1907] TS 910

Voller, R., (Acting Commissioner of Companies and Intellectual Property Commission), 2016, Notice no. 20 to customers: Non-disclosure of remuneration and benefits of directors and prescribed officers in annual financial statements, 14 March 2016, viewed 09 June 2017, from http://www.cipc.co.za/files/8414/5796/3772/ Notice 20 of 2016.pdf

Webster's New World College Dictionary, 4th edn., n.d., viewed 22 May 2017, from http://www.yourdictionary.com/value\#websters 


\section{Appendix 1}

TABLE 1-A1: Calculations of values disclosed in Table 7.

\begin{tabular}{|c|c|c|c|c|c|c|}
\hline Reporting date & $\begin{array}{l}\text { Fair value on } \\
\text { grant date }\end{array}$ & $\begin{array}{l}\text { Fair value on } \\
\text { vesting date }\end{array}$ & $\begin{array}{l}\text { Fair value at } \\
\text { reporting date }\end{array}$ & Gain on exercise & IFRS 2 expense & $\begin{array}{l}\text { Intrinsic value on } \\
\text { reporting date }\end{array}$ \\
\hline $20 \times 1$ & $\mathrm{R} 2 \times 100$ & - & $\mathrm{R} 2.80 \times 100$ & - & $100 \times R 2 \times 6 / 36$ & $(R 15.10-15) \times 100$ \\
\hline $20 \times 2$ & - & - & $\mathrm{R} 2.55 \times 100$ & - & $100 \times \mathrm{R} 2 \times 12 / 36$ & $(R 15.80-15) \times 100$ \\
\hline $20 \times 4$ & - & $\mathrm{R} 3 \times 100$ & $\mathrm{R} 2.70 \times 100$ & - & $100 \times R 2 \times 6 / 36$ & $(R 17.00-15) \times 100$ \\
\hline $20 \times 5$ & - & - & $\mathrm{R} 2.85 \times 100$ & - & - & $(R 17.10-15) \times 100$ \\
\hline $20 \times 6$ & - & - & $\mathrm{R} 2.60 \times 100$ & - & - & $(R 17.50-15) \times 100$ \\
\hline $20 \times 8$ & - & - & $\mathrm{R} 1.55 \times 100$ & $(\mathrm{R} 16-15) \times 100$ & - & $(R 16.50-15) \times 100$ \\
\hline $20 \times 9$ & - & - & $\mathrm{R} 1.70 \times 100$ & - & - & $(R 16.90-15) \times 100$ \\
\hline
\end{tabular}

